\title{
災害に対するレジリエンスの 向上に向けて
}

2011 年3月11日に発生した東北地方太平洋沖地震 ·津波（以下3.11 と略記）により 引き起こされた東日本大震災は、それまでの堤防の増強や建物の耐震化等の八一ド面で の防災対策の強化にもかかわらず、我が国に災害に対する深刻な脆弱性がなお存在し、 その克服にはソフト面や精神面を含む総合的な取り組みが必要であることを如実に示し た。日本学術会議はその状況に鑑み、また、国際アカデミ一が2012年5月に発出した「G8 サミットに向けた共同声明」に述べられていた多岐にわたる課題を統合的に審議するた め、東日本大震災復興支援委員会に「災害に対するレジリエンスの構築分科会」を設置 した。この分科会は会員・連携会員に対する公募に応じて参集した医学、法学、情報学、 工学、理学など幅広い領域の專門家30名と外部の專門家1名の計31名からなるもので、 近年学際的活動に力を入れている日本学術会議においても際立って学際性の強いもので あつた。

レジリエンスという言葉は專門領域によりその意味するところにかなりの開きがあ り、この分科会の審議もそれについての共通理解を得るところから始められた。その結 果、時に激しい議論を戦わせつつも、レジリエンスを「想定を超える極端現象に遭遇し てもできるだけ平常の営みを損なわない、また被害が避けられない場合でもそれを極力 抑え、被害を乗り越え復活する力」とする共通理解に至つた。そして、社会・経済シス テムのみならず、人の生活や精神的側面をも含む包括的な観点からその向上を図るべく、 提言を取りまとめることとなった。ただしこの言葉の実際の適用に当たつては、専門領 域により、其々の事情を踏まえた指標の設定や定式化が行なわれた。

我が国の災害に対するレジリエンスを高めるにはどのような課題が克服されねばなら ないのか、また東日本大震災は我が国のレジリエンスにいかなる影響を与え、またそれ に関連して社会はどのように変わったのか、そしてレジリエンスを高めるために今我々 は具体的に何をなすべきなのか、などの問いに答えるべく分科会は審議を重ね、提言「災 害に対するレジリエンスの向上に向けて」を取りまとめ、2014年9月22日にそれを公 表した。この提言には、災害に対するレジリエンスの向上に向けた現状と問題点につい ての多角的観点から見た説明、および、それらを克服するための6項目20件の提案が記 されている。

3.11 後我が国の災害に対するレジリエンスが向上しているかどうかの評価を現時点で することは時期尚早かもしれないが、この言葉の使用頻度が3.11 以来全国的否全世界的 に大幅に高まったのは確かであろう。また、本誌の表紙の写真に見られるように、その 
向上に資すると考えられる様々な努力が東日本大震災の被災地をはじめとして全国的に なされてきたのも事実である。しかしその一方で、時間の経過とともに人々の心から震 災の記憶が次第に薄れ、3.11後高まりを見せた防災意識にも陰りが見え始め、短期的な 経済上の理由等から深刻なリスクの高まりをつい軽視したり、看過したり、はたまた無 視したりする風潮も、昨今目立つようになってきた。東日本大震災が未だ収束からほど 遠く、今なお多くの国民が仮設住宅等での不自由な生活や将来への絶望感に苛まれてい るにも拘らず、である。

この提言を社会に広く認知し、理解し、活用していただくための活動の一環として公 開シンポジウムを開催したのは、提言公表か56日後の2014年9月28日であった。そ己 で提言で取り上げられている「継続的なリスク監視と日常的なリスクに対する備えの充 実」「レジリエンス向上のための防災·減災の推進」「こころの回復を支える体制の整備」 「公衆衛生システムの改善」「情報通信技術の一層の活用」「開発援助プログラムへのレ ジリエンス能力の統合と活用」などのテーマについて、現状と問題点およびそれらに対 する提言の趣旨と意義などを、具体的事例を用いて紹介した。また、最後に総合討論の 時間を設け、フロアとの間の相互理解と議論の深化を図った。このような活動を根気よ く続けること自体が、東日本大震災の経験亡教訓の風化を防ぎ、我が国の災害に対する レジリエンスを高める上で大切だと思われる。

本特集は、上記の提言およびシンポジウムの成果を広く社会に発信し、活用していた だくために企画したものである。我が国の災害に対するレジリエンスの向上およびそれ と関連する議論の深化にいささかでも役立てていただければ幸いである。なお、提言「災 害に対するレジリエンスの向上に向けて」の全文は日本学術会議 HPのhttp:/ / www.sci. go.jp/ja/info/kohyo/pdf/kohyo-22-tl40922.pdfにに掲載されており、また、公開シン ポジウム「災害に対するレジリエンスの向上に向けて」において各講師により用いられ たパワーポイントはhttp://www.sci.go.jp/ja/event/140928.html でで覧いただけるの で、是非ご活用いただきたい。

日本学術会議第三部会員 